\title{
Hubungan antara Umur dan Paritas dengan Kejadian Abortus Imminens di RS.AR Bunda Kota Prabumulih Tahun 2019
}

\section{Wulan Citra Sari}

Akademi Kebidanan Budi Mulia Prabumulih

Informasi Artikel :

Diterima : 10 April 2020

Direvisi : 25 April 2020

Disetujui : 15 Mei 2020

*Korespondensi Penulis : wulancitra797@gmail.com

\section{A B S T R A K}

World Health Organization (WHO) memperkirakan bahwa angka kematian ibu yang disebabkan oleh abortus sekitar 15-50\%, di Asia Tenggara setiap tahun sebesar 4,2 juta ibu hamil mengalami Abortus termasuk Indonesia mengalaminya dimana angka kejadian tersebut mencapai 750.000 sampai 1,5 juta pertahun. Tujuan penelitian ini adalah untuk mengetahui hubungan antara umur dan paritas ibu terhadap kejadian abortus imminens. Hubungan faktor faktor tersebut dicari mengunakan metode survey analitik dengan pendekatan cross sectional. Untuk populasi dalam penelitian ini adalah semua ibu hamil trimester I dan II yang pernah dirawat di zaal kebidananan RS. AR. Bunda Prabumulih tahun 2019 yang berjumlah 278 orang. Sedangkan sampel penelitian ini adalah total populasi sebanyak 278 orang. Dari hasil analisa bivariat didapatkan faktor-faktor yang berhubungan dengan kejadian abortus imminens yaitu faktor umur dimana P. Value $=0,000$ lebih kecil dari P.Value $=0,05$ dan faktor paritas dimana P.Value $=0,000$ lebih kecil dari P.Value $=0,05$. Sehingga semua faktor yang diteliti berhubungan terhadap kejadian abortus imminens.

Kata Kunci : $\quad$ Abortus Imminens, Umur, Paritas

Keywords: Abortus Imminens, Age, Parity.

The World Health Organization (WHO) estimates that the maternal mortality rate due to abortion is around 15-50\%, in Southeast Asia every year 4,2 millions pregnant women experience Abortus including Indonesia experience where the incidence rate reaches 750,000 to 1.5 million per year. The purpose of this study was to determine the relationship between age and parity of the mother to the incidence of abortus imminens. The factor factor relationship was searched using analytical survey method with cross sectional approach. For the population in this study were all pregnant women of trimester I and II who had been treated in hospital obstetrics. AR. Bunda Prabumulih in 2019 which amounted to 278 people. While the sample of this study is a total population of 278 people. From the result of bivariate analysis, it is found that factors related to the occurrence of abortus imminens are age factor where P. Value $=0.000$ is smaller than P.Value $=0,05$ and parity factor where P.Value $=0.000$ is less than $P$. Value $=0,05$. So all the factors studied relate to the incidence of abortus imminens. 


\section{PENDAHULUAN}

Kehamilan adalah suatu peristiwa yang di tunggu-tunggu oleh wanita. Tapi disamping itu kehamilan juga dapat menimbulkan berbagai komplikasi, salah satunya adalah Abortus merupakan momok bagi setiap ibu hamil. Abortus memang paling ditakuti oleh banyak wanita hamil. Abortus bisa saja terjadi secara tiba-tiba tanpa ada sebabnya. ${ }^{1}$

Abortus adalah pengakhiran kehamilan dengan pengeluaran hasil konsepsi sebelum janin mampu untuk hidup di luar kandungan. Kejadian abortus sangat berbahaya bagi keselamatan dan kesehatan wanita terutama jika dilakukan secara sembarang oleh tenaga yang tidak terlatih. Jumlah kejadian abortus yang dialami oleh wanita baik disengaja maupun tidak disengaja dan setiap tahunnya mengalami peningkatan yang cukup memprihatinkan, sebagai konsekuensinya jumlah kematian ibu mengalami peningkatan akibat komplikasi dari pada abortus yaitu perdarahan terus-menerus serta infeksi pada jalan lahir. ${ }^{2}$

Abortus imminens itu sendiri merupakan terjadinya perdarahan bercak yang menunjukkan ancaman terhadap kelangsungan suatu kehamilan. Dalam kondisi seperti ini, kehamilan masih mungkin berlanjut atau mungkin dipertahankan. ${ }^{3}$

Dalam rangka meningkatkan Indeks Pembangunan Manusia Indonesia secara umum terutama pembangunan dibidang kesehatan saat ini masih jauh dari harapan, hal ini di tandai dengan masih banyaknya ditemui kasus-kasus aborsi maupun abortus yang berakhir dengan kematian hingga $15 \%$ sampai $45 \%$ yang disebabkan oleh komplikasi abortus. ${ }^{4}$

World Health Organization (WHO) memperkirakan bahwa angka kematian ibu yang disebabkan oleh abortus sekitar 15-50\%, di Asia Tenggara setiap tahun sebesar 4,2 juta ibu hamil mengalami Abortus termasuk Indonesia mengalaminya dimana angka kejadian tersebut mencapai 750.000 sampai 1,5 juta pertahun. ${ }^{5}$

Menurut laporan WHO sekitar 98-99\% kematian maternal terjadi di negara berkembang. Sekitar sepertiga kematian terjadi akibat pertolongan pengguguran kandungan yang tidak aman dan tidak bersih. Penyebab utama masih tetap trias penyebab kematian berupa perdarahan $60 \%$, infeksi $25 \%$, dan gestosis $15 \%$. Penyebab lainnya hanya menimbulkan kematian pada $5 \%$ kematian maternal). Kontribusi angka kematian ibu dan anak di Indonesia cukup besar, dimana kematian maternal terjadi setiap 2,0-2,5 menit. ${ }^{6}$

Berdasarkan data Wold Health Organization

(WHO), terdapat 600.000 ibu hamil dan bersalin meninggal setiap tahun diseluruh dunia. Negaranagara maju Angka kematian ibu pertahun hanya 27 per 100.000 kelahiran hidup, sedangkan di Negara negara yang sedang berkembang AKI rata-rata mencapai 480 per 100.000 kelahiran hidup. $^{7}$

Angka Kematian Ibu didunia pada tahun 2015 yaitu mencapai 303.000 jiwa, Afrika utara 201.000 jiwa, Asia Tenggara 13.000,dan Amerika 7300 jiwa. AKI di negara-negara Asia Tenggara itu sendiri seperti Indonesia 126 per 100.000 kelahiran hidup Filipina 114 per 100.000 kelahiran hidup, Vietnam 54 per 100.000 kelahiran hidup, Thailand 20 per 100.000 kelahiran hidup, Brunei 23 per 100.000 kelahiran hidup, dan Malaysia 40 per 100.000 kelahiran hidup.

Hal ini disebabkan oleh perdarahan $42 \%$, keracunan kehamilan (eklampsia) $13 \%$, abortus $11 \%$, infeksi $10 \%$, persalinan macet $9 \%$ dan penyebab lain $15 \%$. Selain itu terdapat juga penyebab tidak langsung, yakni status nutrisi ibu hamil yang rendah, anemia pada ibu hamil, terlambat mendapat pelayanan, serta usia yang tidak ideal dalam melahirkan, dan terlalu dekat jarak melahirkan. ${ }^{8}$

Lebih dari $80 \%$ abortus terjadi pada 12 minggu pertama kehamilan. Kelainan kromosom merupakan penyebab paling sedikit separuh dari kasus abortus dini ini, selain itu banyak faktor yang mempengaruhi terjadinya abortus antara lain : paritas, umur ibu, umur kehamilan, kehamilan tidak diinginkan, kebiasaan buruk selama hamil, serta riwayat keguguran sebelumnya. Frekuensi abortus yang secara klinis terdeteksi meningkat dari $12 \%$ pada wanita berusia kurang dari 20 tahun, menjadi $26 \%$ pada wanita berumur 40 tahun sehingga kejadian perdarahan spontan lebih berisiko pada ibu dibawah usia 20 tahun dan diatas 35 tahun. $^{8}$

Hal di atas menunjukkan suatu realita yang harus diketahui oleh wanita hamil bahwa ia bisa terancam keguguran. Pada kenyataannya, data yang diperoleh dari catatan rekam medik RS.AR Bunda kota Prabumulih dari bulan JanuariDesember 2018 terjadi sebanyak 98 kasus dengan kejadian abortus imminens dari seluruh ibu hamil trimester I dan II yang pernah dirawat di RS tersebut yang berjumlah 278 orang dengan berbagai kasus kebidanan lainnya.

Berdasarkan data di atas penulis tertarik untuk melakukan penelitian dengan judul "Hubungan Antara Umur dan Paritas Ibu Hamil dengan Kejadian Abortus Imminens di Rumah Sakit AR. Bunda Kota Prabumulih Tahun 2019”. 


\section{METODE PENELITIAN}

Teknik pengumpulan data dengan menggunakan data sekunder yaitu data yang diperoleh dari rekam medis RS AR Bunda Kota Prabumulih. Instrumen pengumpulan data Abortus imminens dengan menggunakan chek list.Data yang diperoleh dianalisis dalam suatu pembahasan dengan komputerisasi. ${ }^{9}$

Analisa univariat dilakukan terhadap tiap variabel dari hasil penelitian untuk menghasilkan distribusi ftrkuensi dan presentase dari tiap variabel adapun variabel independen diteliti yaitu (malpresentasi, tinggi badan dan partus lama) dan variabel dependen yaitu ( persalinan sektio cesarea ) dalam bentuk table.

Analisis bivariat Meupakan analisis yang dilakukan terhadap 2 variabel yang diduga berhubungan atau berkolerasi pada penelitian ini analisis dilakukan terhadap variabel indenpenden ( umur dan paritas) yang diduga berhubungan terhadap variabel dependen (Ab. Imminens) pada analisis di Bivariat ini akan mengguankan Uji statistik, Chi Square tes dengan batas kemaknaan $a=0,05$ hasil keputusan statistik diperoleh dengan membandingkan $\mathrm{p}$ value dengan nilai $\mathrm{a}=0,05$ bila $\mathrm{p}$ value $0,5<0,05$ berarti ada hubungan yang bermakna dan bil $\mathrm{p}$ value $>0,05$ berarti tidak ada hubungan yang bermakna antara variabel independen dengan variabel dependen. Analisis dilakukan dengan menggunakan proses komputerisasi dengan menggunakan aplikasi dengan menggunakan aplikasi komputer SPSS ( Statistical Program for Social Science ). ${ }^{9}$

\section{HASIL PENELITIAN}

\section{Analisis Univariat}

Analisis ini dilakukan untuk mengetahui distribusi frekuensi dan persentase variabel independen dan dependen yaitu umur dan paritas ibu serta kejadian abortus imminens di RS. AR. Bunda Prabumulih tahun 2019. Untuk lebih jelas dapat dilihat pada uraian dibawah ini:

\section{Variabel Dependen}

\section{Abortus Imminens}

Tabel 1 Distribusi Frekuensi Kejadian Abortus Imminens di RS AR Bunda Kota Prabumulih Tahun 2019

\begin{tabular}{|c|c|c|c|}
\hline No & Abortus Imminens & Frekuensi & $\%$ \\
\hline 1 & Ya & 180 & 35 \\
\hline 2 & Tidak & 98 & 65 \\
\hline & Jumlah & 278 & 100 \\
\hline
\end{tabular}

Berdasarkan tabel 1 diatas dari 278 responden didapatkan ibu dengan $\mathrm{Ab}$. Imminens berjumlah 98 orang $(35 \%)$ dan ibu yang tidak $\mathrm{Ab}$ Imminens berjumlah 180 orang $(65 \%)$.

\section{Variabel Independen}

\section{a. Umur}

Tabel 2 Distribusi Frekuensi Responden Berdasarkan Umur di RS AR Bunda Kota Prabumulih Tahun 2019

\begin{tabular}{|c|c|c|c|}
\hline No & Umur & Frekuensi & $\%$ \\
\hline 1 & Beresiko & 59 & 43 \\
\hline 2 & Tidak Beresiko & 119 & 57 \\
\hline & Jumlah & 278 & 100 \\
\hline
\end{tabular}

Berdasarkan tabel 2 diatas dari 278 responden didapatkan ibu yang umur tidak beresiko sebanyak 119 (57\%) responden lebih besar dibandingkan dengan ibu yang beresiko sebanyak $59(43 \%)$

\section{b.Paritas}

Tabel 3 Distribusi Frekuensi Responden Berdasarkan Paritas Ibu di RS AR Bunda Kota Prabumulih Tahun 2019

\begin{tabular}{|c|c|c|c|}
\hline No & Parita Ibu & Frekuensi & $\%$ \\
\hline 1 & Tinggi & 54 & 19 \\
\hline \multirow[t]{2}{*}{2} & Rendah & 224 & 81 \\
\hline & Jumlah & 278 & 100 \\
\hline
\end{tabular}

Berdasarkan tabel 3 diatas diatas dari 278 responden dapat diketahui bahwa Paritas ibu resiko rendah sebanyak 224 (81\%) responden lebih besar dibandingkan dengan Paritas resiko tinggi sebanyak 54 responden $(19 \%)$

\section{Analisis Bivariat}

Analisa ini dilakukan untuk mengetahui hubungan antara variabel dependen seksio sesaria dengan variabel independen Malprestasi, Tinggi badan, dan partus lama. Penelitian ini dilakukan untuk melihat apakah ada hubungan antara variabel independen dan variabel dependen dengan menggunakan uji statistik Chi-Square dengan $\alpha=0,05$ dan $\mathrm{df}=1$ dengan batas kemaknaan $p$ value $\leq 0,05$ ada hubungan yang bermakna, dan $p$ value $>0,05$ tidak bermakna.

\section{Hubungan Umur dengan Abortus Imminens di RS AR Bunda Kota Prabumulih Tahun 2019}


Tabel 4 Distrubusi Hubungan umur dengan Kejadian Abortus Imminens di RS AR Bunda Kota Prabumulih Tahun 2019

\begin{tabular}{|c|c|c|c|c|c|c|c|c|}
\hline \multirow{3}{*}{ No } & \multirow{3}{*}{ Umur } & \multicolumn{4}{|c|}{ Abortus Imminens } & & & \multirow{3}{*}{$\begin{array}{c}P \\
\text { Value }\end{array}$} \\
\hline & & \multicolumn{2}{|c|}{ Ya } & \multicolumn{2}{|c|}{ Tidak } & \multicolumn{2}{|c|}{ Total } & \\
\hline & & $\mathbf{N}$ & $\%$ & $\mathbf{N}$ & $\%$ & $\mathbf{N}$ & $\%$ & \\
\hline 1 & Beresiko & 85 & 31 & 34 & 12 & 119 & 100 & 0,000 \\
\hline \multirow[t]{2}{*}{2} & $\begin{array}{l}\text { Tidak } \\
\text { Beresiko }\end{array}$ & 13 & 4 & 146 & 52 & 159 & 100 & $\begin{array}{c}\text { berma } \\
\text { kna }\end{array}$ \\
\hline & Jumlah & 98 & & 180 & & 278 & & \\
\hline
\end{tabular}
disimpulkan bahwa proporsi untuk responden dengan umur ibu yang beresiko dengan abortus imminens ibu hamil ya sebanyak 85 orang (31\%) sedangkan yang tidak abortus imminens sebanyak 34 orang (12\%). Untuk umur ibu yang tidak beresiko dengan abortus imminens ibu hamil ya sebanyak 13 orang (4\%) sedangkan yang tidak abortus imminens sebanyak 146 orang $(53 \%)$.

Hasil uji Chi-Square menunjukan bahwa ada hubungan yang bermakna antara umur ibu terhadap kejadian abortus imminens ibu hamil dimana P.Value $=0,000$ lebih kecil dari 0,05. Dengan demikian hipotesa yang menyatakan ada hubungan antara umur ibu terhadap kejadian abortus imminens diterima.

\section{Hubungan Paritas dengan Abortus Imminens \\ Tabel 5 Distribusi Hubungan Paritas dengan Kejadian Abortus Imminens di RS. AR Bunda Kota Prabumulih}

\begin{tabular}{|c|c|c|c|c|c|c|c|c|}
\hline \multirow{3}{*}{$\begin{array}{l}\mathbf{N} \\
\mathbf{0}\end{array}$} & \multirow[b]{3}{*}{ Paritas } & \multicolumn{4}{|c|}{ Abortus Imminens } & \multirow{2}{*}{\multicolumn{2}{|c|}{ Total }} & \multirow[b]{3}{*}{ No } \\
\hline & & \multicolumn{2}{|c|}{ Ya } & \multicolumn{2}{|c|}{ Tidak } & & & \\
\hline & & n & $\%$ & n & $\%$ & $\mathbf{n}$ & $\%$ & \\
\hline 1 & Tinggi & 32 & 11 & 22 & 8 & 54 & 19 & \multirow{3}{*}{0,000} \\
\hline 2 & Rendah & 66 & 24 & 158 & 57 & 224 & 81 & \\
\hline & Total & 98 & 35 & 180 & Total & 278 & & \\
\hline
\end{tabular}

Berdasarkan Tabel 5 dapat disimpulkan bahwa proporsi untuk responden dengan paritas tinggi dengan kejadian abortus imminens ya sebanyak 32 orang $(11 \%)$ sedangkan yang tidak abortus imminens sebanyak 22 orang $(8 \%)$. Untuk paritas rendah dengan abortus imminens sebanyak 66 orang (24\%) sedangkan yang tidak abortus imminens sebanyak 158 orang $(57 \%)$.

Hasil uji Chi-Square menunjukan bahwa ada hubungan yang bermakna antara paritas terhadap kejadian abortus immienens dimana P.Value = 0,000 lebih kecil dari 0,05. Dengan demikian hipotesa yang menyatakan ada hubungan antara paritas terhadap kejadian abortus imminens diterima.

\section{PEMBAHASAN}

Penelitian ini menggunakan desain cross sectional, Penelitian ini hanya sebatas mencari antara variabel independen (Abortus Imminens) dengan variabel independen (umur dan paritas) dengan menggunakan Uji-Square serta medical record sebagai alat yang digunakan untuk mengumpulkan data melalui checklist. ${ }^{9}$

Sampel penelitian adalah sebagian dari populasi yang diambil dari keseluruhan objek yang diteliti dan dianggap mewakili seluruh populasi, cara pengambilan dilakukan dengan caraSimple Random Sampling (Secara acak sederhana) ${ }^{9}$, dimana sample yaitu sebagian ibu yang melahirkan di Rumah Sakit AR Bunda Kota Prabumulih Tahun 2018 berjumlah 278 orang. Pembahasan penelitian ini terdiri dari analisis univariat dan analisis bivariat dan akan diuraikan sebagai berikut :

\section{Abortus Imminens}

Abortus imminens didefenisikan sebagai perdarahan bercak yang menunjukkan ancaman terhadap kelangsungan suatu kehamilan. Dalam kondisi seperti ini, kehamilan masih mungkin berlanjut atau mungkin dipertahankan. ${ }^{10}$

Dari tabel 1 diatas terlihat bahwa ibu yang abortus imminens berjumlah 98 orang $(35 \%)$ dan ibu yang tidak mengalami abortus imminens berjumlah 180 orang (65\%). Keadaan ini menunjukan bahwa persentase ibu hamil yang mengalami abortus imminens lebih sedikit dibandingkan dengan ibu hamil yang tidak mengalami abortus imminens di RS. AR. Bunda Prabumulih tahun 2019.

Pada penelitian yang dilakukan di RS. AR. Bunda Prabumulih tahun 2019 setelah dilakukan analisa data diperoleh beberapa penyebab abortus imminens yang terjadi pada ibu hamil sesuai yang di teliti seperti umur ibu saat hamil yang rentan sehingga beresiko untuk terjadinya abortus khususnya abortus imminens selain itu jumlah anak yang dilahirkan sebelumnya beresiko untuk terjadinya abortus khususnya abortus imminens.

Hal ini sesuai dengan teori Cunningham, 2005 yang menyatakan bahwa kejadian abortus imminens di pengaruhi oleh beberapa faktor, yaitu umur, paritas, pendidikan, status ekonomi, status perkawinan dan tempat tinggal.

Hal ini serupa dengan hasil penelitian yang dilakukan oleh Eva Rusdiana 2006 di Jawa Barat yang melihat rata rata kejadian 
abortus imminens pada ibu hamil di wilayah tersebut ternyata ditemukan ibu hamil yang dengan kasus tersebut. Walaupun begitu persentase kejadiannya belum mendominasi dibandingkan yang kejadian abortus yang lainnya.

Disarankan bagi ibu hamil untuk ke depannya dapat mengenali tanda tanda bahaya dan resiko yang dapat memberatkan dalam kehamilan dengan cara konsultasi dengan tenaga kesehatan sehingga dapat memahami dan menghindari kejadian yang tidak diinginkan selama kehamilan khususnya untuk kasus abortus imminens.

\section{Hubungan Antara Umur Ibu Terhadap Kejadian Abortus Imminens}

Umur merupakan ukuran untuk menunjukkan seberapa lama manusia hidup. Setiap tahapan kehidupan seseorang senantiasa memberi kontribusi penting dalam proses kehidupannya termasuk saat kesiapan mereka dianggap cocok untuk suatu kehamilan .

Dari tabel diatas dapat disimpulkan bahwa proporsi untuk responden dengan umur ibu yang beresiko dengan abortus imminens ibu hamil ya sebanyak 85 orang (31\%) sedangkan yang tidak abortus imminens sebanyak 34 orang (12\%). Untuk umur ibu yang tidak beresiko dengan abortus imminens ibu hamil ya sebanyak 13 orang (4\%) sedangkan yang tidak abortus imminens sebanyak 146 orang (53\%). Hasil uji Chi-Square menunjukan bahwa ada hubungan yang bermakna antara umur ibu terhadap kejadian abortus imminens ibu hamil dimana P.Value $=0,000$ lebih kecil dari 0,05. Dengan demikian hipotesa yang menyatakan ada hubungan antara umur ibu terhadap kejadian abortus imminens diterima.

Pada penelitian di RS. AR. Bunda Prabumulih tahun 2019 didapat bahwa umur dapat mempengaruhi kejadian abortus imminens. Pengaruh umur ibu yang beresiko terhadap kejadian abortus imminens disebabkan karena umur ibu hamil yang menjadi responden penelitian ini saat dirawat dengan diagnosa abortus imminens rentan untuk terjadinya abortus yaitu terlalu muda ataupun terlalu tua hal tersebut juga merupakan faktor predisposisi terjadinya abortus imminens.

Hal ini sesuai dengan pendapat Wiknjosastro yang menyatakan bahwa Di dalam ukuran umur reproduksi yang sehat dikenal bahwa usia aman untuk kehamilan adalah 20-30 tahun, kematian maternal pada wanita hamil dan melahirkan pada usia di bawah 20 tahun ternyata $2-5$ kali lebih tinggi dari pada usia 20-29 tahun, kematian maternal meningkat kembali setelah usia 30-35 tahun.

Hal ini sesuai dengan teori Cunningham yang menyatakan bahwa kejadian abortus imminens di pengaruhi oleh beberapa faktor, yaitu umur, paritas, pendidikan, status ekonomi, status perkawinan dan tempat tinggal.

Hal ini serupa dengan penelitian yang dilakukan oleh Ahmad di RSU Dati II Semarang tahun 2009 yang menunjukkan bahwa ibu dengan umur lebih dari 30 tahun tiga kali mempunyai risiko lebih besar untuk mengalami abortus. Penelitian lain yang mendukung penelitian ini adalah penelitian yang dilakukan oleh Darman di jawa tenggah tahun 2007 yang menunjukkan adanya pengaruh umur lebih dari 30 tahun terhadap kejadian abortus.

Disarankan kedepannya bagi ibu hamil untuk berperan aktif dalam berkonsultasi ke petugas kesehatan mengenai masalah kehamilan terutama umur saat kehamilan sehingga dapat menghindari kejadian yang tidak diinginkan terutama kasus abortus imminens.

\section{Hubungan Antara Paritas Ibu Terhadap Kejadian Abortus Imminens.}

Paritas adalah jumlah anak yang pernah dilahirkan oleh seorang ibu baik hidup ataupun mati.$^{10}$

Dari tabel diatas dapat disimpulkan bahwa proporsi untuk responden dengan paritas tinggi dengan kejadian abortus imminens ya sebanyak 32 orang (11\%) sedangkan yang tidak abortus imminens sebanyak 22 orang (8\%). Untuk paritas rendah dengan abortus imminens sebanyak 66 orang (24\%) sedangkan yang tidak abortus imminens sebanyak 158 orang (57\%). Hasil uji Chi-Square menunjukan bahwa ada hubungan yang bermakna antara paritas terhadap kejadian abortus imminens dimana P.Value $=0,000$ lebih kecil dari 0,05. Dengan demikian hipotesa yang menyatakan ada hubungan antara paritas terhadap kejadian abortus imminens diterima.

Pada penelitian di RS. AR. Bunda Prabumulih tahun 2019 didapat bahwa paritas dapat mempengaruhi kejadian abortus imminens. Pengaruh paritas yang tinggi terhadap kejadian abortus imminens disebabkan karena paritas ibu yang dirawat dengan diagnosa abortus imminens memiliki jumlah anak yang rentan yaitu terlalu banyak sehingga dapat berisiko terjadinya kasus abortus imminens. 
Hal ini sesuai dengan pendapat Prawirohardjo yang menyatakan bahwa paritas 2-3, merupakan paritas paling aman ditinjau dari sudut kematian maternal. Paritas satu dan paritas tinggi (lebih dari 3) mempunyai angka kematian maternal lebih tinggi. Resiko pada paritas satu dapat ditangani dengan asuhan obstetrik yang lebih baik, sedangkan resiko pada paritas tinggi dapat dikurangi atau dicegah dengan keluarga berencana. Sebagian kehamilan pada paritas tinggi adalah tidak direncanakan.

Hal ini sesuai dengan teori Cunningham yang menyatakan bahwa kejadian abortus imminens di pengaruhi oleh beberapa faktor, yaitu umur, paritas, pendidikan, status ekonomi, status perkawinan dan tempat tinggal.

Penelitian ini sesuai dengan hasil penelitian yang dilakukan oleh Sutrianty di RSIA Siti Fatimah tahun 2006 yang menunjukkan bahwa ibu dengan paritas 24 menunjukkan adanya pengaruh paritas ibu dengan kejadian abortus. lbu dengan paritas lebih dari tiga kali mempunyai risiko lebih besar untuk mengalami abortus. Penelitian lain yang mendukung penelitian ini adalah penelitian yang dilakukan oleh Sry Rahayu di RSU Lasinrang Pinrang tahun 2009 yang menunjukkan adanya pengaruh paritas tinggi dengan kejadian abortus.

Disarankan kedepannya bagi ibu hamil untuk berperan aktif dalam berkonsultasi ke petugas kesehatan mengenai masalah kehamilan terutama paritas saat kehamilan sehingga dapat menghindari kejadian yang tidak diinginkan terutama kasus abortus imminens.

\section{KESIMPULAN}

Berdasarkan hasil penelitian yang dilaksanakan di RS.AR Bunda Kota Prabumulih dari tanggal 10 Juli sampai dengan 02 September 2019 dengan sampel sebanyak 278 orang, mengenai hubungan umur dan paritas ibu dengan kejadian Abortus imminens, , maka dapat ditarik kesimpulan ada hubungan yang bermakna umur dan paitas ibu secara persial dengan Kejadian Abortus Imminens di RS.AR Bunda Kota Prabumulih Tahun 2019.

\section{DAFTAR PUSTAKA}

1. Hidayat, Aziz Alimul. 2010. Metode Penelitian Kebidanan Dan Teknik Analisis Data. Salemba medika : Jakarta
2. Prawihardjo, Sarwono. 2007. Ilmu Kebidanan. Yayasan Bina Pustaka: Jakarta

3. Cunningham 2005. Faktor Faktor Yang Mempengaruhi Abortus Pada Ibu Hamil. Http://www,depkes.go.id accessed 5 februari $\underline{2019)}$

4. Dinas Kesehatan Sumatera Selatan. 2010. Profil Kesehatan Kota Palembang. Indonesia

5. Depkes. 2015. Survey Demografi Dan Kesehatan Indonesia (SDKI)

6. Dinas Kesehatan Kota Prabumulih. 2019.

7. Geri. 2009. Obstetri Dan Ginekologi Panduan Praktik. Buku kedokteran EGC: Jakarta

8. Suparyanto. 2012. Konsep Dasar kehamilan. Salemba medika : Jakartal

9. Notoatmodjo, Soekidjo. 2016. Metodologi Penelitian Kesehatan. Rineka Cipta: Jakarta

10. Manuaba IGB. 2015. Ilmu Kebidanan Penyakit Kandungan dan Keluarga Berencana untuk pendidikan bidan. Buku kedokteran EGC : Jakarta 